\title{
尿中の白血球の貪食能の検討
}

岐阜大学医学部泌尿器科学教室 前 田真 一
(主任 : 西浦常雄教授)

\section{STUDIES ON THE PHAGOCYTIC FUNCTION OF URINARY LEUKOCYTES}

\author{
Shin-ichi Maeda \\ Department of Urology, Gifu University School of Medicine \\ (Director: Prof. T. Nishiura, M.D.)
}

The phagocytic function of urinary leukocytes of patients with urinary tract infection (UTI) was studied.

Urinary leukocytes were alive irrespective of the type of UTI, urine osmolarity or $\mathrm{pH}$. The mean rate of the viability was observed to be $82 \%$. The rate of phagocytosis, the percentage of leukocyte phagocytizing bacteria in all urinary leukocytes, was high under the urine condition of low osmolarity $(\leqq 600 \mathrm{mOsm} / \mathrm{L})$ and nearly neutral $\mathrm{pH}$. The mean rates of phagocytosis of patients with acute cystitis, acute pyelonephritis, chronic cystitis, and chronic pyelonephritis were $3.0 \%, 2.1 \%, 13.2 \%$, and $18.3 \%$, respectively. The rate of phagocytosis of acute UTI was kept very low regardless of urine bacterial count; however, in chronic UTI, this rate increased in accordance with urine bacterial count.

The rate of phagocytosis of patients with indwelling catheters was higher than that of patients without catheters.

All chronic cystitis patients with indwelling catheters and $58 \%$ of chronic cystitis patients without catheters showed to have positive tests for antibody-coated bacteria (ACB). The opsonic effect of ACB could not be confirmed.

The phagocytic function of urinary leukocytes was also studied in vitro. By the Lab-Tek chamber method, the rate of phagocytosis was 20 to $30 \%$ in normal and infected urine regardless of urine osmolarity. By the tube method, the phagocytosis was almost none in urine with osmotic pressure higher than $600 \mathrm{mOsm} / \mathrm{L}$, and even in urine with osmotic pressure lower than $600 \mathrm{mOsm} / \mathrm{L}$ the rate of phagocytosis was lower than $5 \%$ in many cases.

However, the rate of phagocytosis apparently increased in urine with osmotic pressure lower than $600 \mathrm{mOsm} / \mathrm{L}$ by centrifuging the tubes, which means acceralated contact of leukocytes and yeasts. No difference in the rate of phagocytosis was observed between normal urine and infected urine.

The following three experiments were counducted by the transmission electron microscope; morphological study of urinary leukocytes of patients with various types of UTI, observation of phagocytosis in infected urine added with latex particles, and that of phagocytosis in aseptic pyuria added with bacteria.

The above results suggest that leukocytes in urine are not mere passive spillover as long considered but taking a part of defense function against ascending UTI.

要旨: 尿路感染症患者の尿中の白血球は平均 $82 \%$ 尘生存しており, 詳細に観察すると, 細菌を貪食して いるものが少なからず認められた。全体の白血球の中で細菌を貪食している白血球が占める割合（貪食 率)の高い尿は浸透圧が $600 \mathrm{mOsm} / \mathrm{L}$ 以下, $\mathrm{pH}$ が 7 ～ 8 であつた。急性膀脂炎, 急性腎孟腎炎, 慢性膀 腅炎, 慢性腎孟腎炎の平均貪食率はそれぞれ，3.0\%，2.1\%，13.2\%，18.3\%であつた。急性症では尿 中細菌の菌数にかかわらず貪食率は低值で, 慢性症では菌数の増加に伴い貪食率が増加した。カテーテ ル留置例は非留置例に比し貪食率は高值であつた。 カテーテル留置の慢性膀朕炎患者は全例 antibody. coated bacteria (ACB) 陽性で, 非留置の慢性膀朕炎患者でも58\%が陽性であつた。 ACB のオプソニ ン効果は明らかでなかつた.末梢血多核球を分離し正常および感染尿中で酵母の貪食実験を施行すると, 
Lab-Tek chamber 法では正常尿, 感染尿とも $800 \mathrm{mOsm} / \mathrm{L}$ 委で浸透圧にかかわらず20〜30\%の白血球が 貪食したが，tube 法では600mOsm/L を越克ると貪食は行なわれず， $600 \mathrm{mOsm} / \mathrm{L}$ 以下でも多くは $5 \%$ 以下であつた。しかし， tube を遠沈し接触機会を増加させると $600 \mathrm{mOsm} / \mathrm{L}$ 以下では著明に増加した。 正常尿と感染尿で貪食率に及洔す差異は認められなかつた。尿路感染症の尿中の白血球の微細構造と, 感染尿に latex 粒子, 無菌性膿尿に大腸菌を注入した場合の貪食状況を電子顕微鏡で確認した. 以上の観 察より尿中の白血球も感染防御の一役を担つているものと考兄られた.

\section{I. 緒 言}

従来, 尿路腔へ遊出した白血球は尿の種々な条件(高

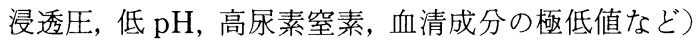
により，汪とんど機能は有さず単なる遊出産物であろ らとされてきた ${ }^{122) 3}$. 一方, 近年 rat の膀胱感染実験で はあるが，膀胱腔内にて多数の好中球が細菌を貪食し ている像が電子顕微鏡的に認められたとする報告4) や，急性膀胱炎患者の尿中の白血球を minimal essential mediumに浮遊させると， $40 \%$ 前後の白血球が latex 粒子を貪食するといら報告5) もる。臨床的に は，淋病の場合に多核白血球の細胞内に多数の淋菌を 認めることができるが，一般細菌に関しては上皮に付 着した尿道常在菌と思われる細菌をしばしば認める程 度と考光られていた。しかし, 我々は慢性尿路感染症 患者の尿を注意深く観察すると，細菌を貪食している 白血球を認めることが少なくないことに気ついたた。 こで今回，尿中の白血球の貪食能について改めて検討 することとした。

まず，尿路感染症（UTI）患者の尿中の白血球が生 存しているか否かを検討し，ついでその中に細菌を貪 食している白血球がどの程度認められるかを疾患群別 に検討した。ささらに, 白血球が尿路腔に遊出した後に も貪食が起こりらる現象であることを証明するため に，ヒトの尿中の白血球がその感染尿中で貪食能を有 するか否かの実験を行ない, 光顕的, 電顕的に観察し た。 また, antibody-coated bacteria (ACB) と尿中 の白血球の細菌貪食率との関係を検討し, $\mathrm{ACB}$ のオプ ソニン効果についても考按した.

\section{II. 検討対象}

検討対象は, UTI を有している外来打よび入院患者 166名で, 詳細は Table 1 に示した. 男性は中間尿, 女 性はカテーテルで採尿した尿を, routine の生化学的 検査の後, その $10 \mathrm{ml} 1,500$ 回転, 10 分間遠沈し, decant して得た沈査を $1 \mathrm{ml}$ 容量のプラスチックスポ イトで吸排擋拌し，そのスポイトで $1 / 2$ 滴をスライドグ ラスにのせ，カバーグラスをのせ400倍で検鏡した．白 血球が 1 視野 10 個以上認められ, dip slide 法による尿
Table 1 No. of cases

\begin{tabular}{l|l|r|r|r}
\hline \multicolumn{2}{c|}{ Clinical diagnosis } & Male & Female & Total \\
\hline \multicolumn{2}{c|}{ Acute pyelonephritis } & 5 & 5 & 10 \\
\hline \multicolumn{2}{c|}{ Acute cystitis } & 0 & 30 & 30 \\
\hline \multirow{3}{*}{$\begin{array}{l}\text { Chronic } \\
\text { pyelonephritis }\end{array}$} & catheter not indwellt & 6 & 19 & 25 \\
\cline { 2 - 5 } & catheter indwellt & 15 & 16 & 31 \\
\cline { 2 - 5 } & total & 21 & 35 & 56 \\
\hline \multirow{3}{*}{$\begin{array}{c}\text { Chronic } \\
\text { cystitis }\end{array}$} & catheter not indwellt & 21 & 22 & 43 \\
\cline { 2 - 5 } & catheter indwellt & 22 & 5 & 27 \\
\cline { 2 - 5 } & total & 43 & 27 & 70 \\
\hline \multicolumn{2}{|c|}{ Total } & 69 & 97 & 166 \\
\hline
\end{tabular}

中細菌培養法で尿中細菌が $10^{4} \mathrm{cells} / \mathrm{ml}$ 以上であつた ものをUTI 症例とし，対象として採用した。

急性腎盘腎炎 (APN) 症例とは, cost-vertebral angle (CVA) pain と $38^{\circ} \mathrm{C}$ 以上の発熱で急性発症した もの, 急性膀胼炎 (AC) 症例とは, 女性で排尿痛と頻 尿で急性発症し，発熱，CVA pain を伴なわないもの， 慢性腎孟腎炎 (CPN) 症例とは, 尿管留置カテーテル もしくは腎瘻が 1 力月以上存在するもの, 又, カテー テルが留置されていない症例は, 男性では腎結石か尿 管結石が存在し, 女性では上部尿路結石 ( 7 例), 神経 因性膀胼 ( 6 例), 膀脱尿管逆流 ( 5 例), 多発性囊胞 腎（１例）などが合併するものであり, 排泄性腎孟造 影で腎杯像の鈍化が認められ, 熱発などの急性症状は 認められないもの, 慢性膀胱炎 (CC) 症例とは, 尿道 留置カテーテルもしくは膀胼瘦が 1 力月以上存在する もの,あるいはカテーテルが留置されていない症例は, 男性では前立腺肥大症 (10例), 膀胱䅡部硬化症 ( 6 例), 膀脱腫瘍 ( 3 例), 前立腺癌 ( 1 例), その他 ( 1 例), 女性では神経因性膀胼 ( 9 例), 膀羘腫瘍 ( 1 例), そ の他（12例）などが合併するもので, これらは上部尿 路感染症の症状や所見を有さず, 排泄性腎孟造影で腎 孟腎杯に慢性腎孟腎炎を示す所見を認めなかつた。な 打多少とも上部尿路感染の合併が疑わしい症例につい ては尿管カテーテル插入による尿培養や, 膀胖造影に よる膀脱尿管逆流の有無の確認を行つた. 


\section{III，実験方法}

1. 尿中の白血球の生存確認に関する予備的検討

（1）生存率の検討方法

8 例の UTI 患者 $(\mathrm{CPN}$ 患者 4 例, CC 患者 3 例, AC 患者 1 例) の膿尿を使用し，先に述べた方法で得られ た沈查に一般に細胞の viability を確認する目的で使 用されている $0.25 \%$ trypan blue, $0.1 \%$ eosin, CytoDiachrome をそれぞれ 1 滴ずつ添加して超生体染色 を行い, 直ちに影微鏡下に細胞を200個数兄各染色液に よる白血球の生存率を測定した。な挍Cyto-Diachrome は Sternheimer が1975年に発表した尿沈査染 色液6で， national fast blue と pyronin Bによる超生 体染色法で Sternheimer-Malbin 染色 ${ }^{7)}$ 同様に白血 球の中で pale-stained cell と colorless cell を生存白 血球とした。

（2）経時的生存率変動

13例の UTI 患者 $(\mathrm{CPN}$ 患者 2 例, CC 患者 5 例, AC 患者 6 例) の膿尿を $28 \sim 30^{\circ} \mathrm{C}$ の室温下に静置し, CytoDiachrome を使用した Sternheimer 染色で経時的に dark-staind cell (dead cell), pale-stained cell (damaged cell), colorless cell (alive cell) の割合を 測定した。

（3）温度の生存率に及ぼす影響

4 名の UTI 患者（全例 CC 患者）の膿尿を $25^{\circ} \mathrm{C}$ と $37^{\circ} \mathrm{C}$ 下に 2 時間静置し，沈査を $0.25 \%$ trypan blue で 超生体染色し生存率を測定した。

2. UTI 患者の尿中の白血球

（1）尿中の白血球の生存率

生存確認に関する予備的検討の結果に基づいて, UTI 患者の尿中の白血球を $0.25 \%$ trypan blue を使用 して生存率測定を行つた。

（2）尿中の白血球の貪食率

先に述べた方法にて得られた尿沈査を牛アルブミン 処理したスライドグラスに 1 滴のせ，カバースリップ 法で塗抹標本を作製し, 乾燥後 Wright 染色し, 顕微鏡 下 $(\times 1,000)$ で100 200個の白血球を観察し， 2 個以 上細菌を貪食している白血球の全体の白血球に対する 比率を貪食率として測定した。

上清の尿は osmometer で浸透圧の測定を行ら一 方，尿試験紙（ヘマコンビステックス III）で $\mathrm{pH}$ の簡 易測定を行つた。

(3) $\mathrm{ACB}$

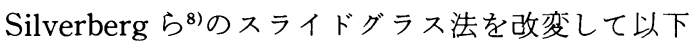
の如く行へた. すなわち, 尿沈査を牛アルブミン処理
した無螢光スライドに塗抹し, 乾燥後, 95\% ethanol で 5 分間固定した。 $0.067 \mathrm{M}$ PBS, pH 7.2で10分間 2 回 洗浄後, 螢光標識抗血清 antihuman immunoglobulins （Behringwerke）を前記 PBS で 6 倍希釈したわのの $0.2 \mathrm{ml}$ を滴下被覆し， moist chamber 内で $37^{\circ} \mathrm{C} 30$ 分間 incubate した. その後PBS で 5 分間 2 回洗浄し, 蒸留 水で洗浄後, 螢光顕微鏡で観察し, ACB 陰性と陽性を 判定した。

\section{(4) 統計処理}

尿中の白血球の生存率・浸透圧・尿中の白血球の細 菌貪食率，ACB 陽性率などについてのUTI 群間比較 の統計手法としては，対応のない $\mathrm{t}$ 検定を用いたが， この場合危険率は両側危険率を採用し，危除率 $5 \%$ を 有意水準と考皇た。

3. 尿中でのヒト多核球のパン酵母貪食能の実験的 検討

多核球の末梢血よりの採取方法は，まずへパリン加 静脈血を $6 \%$ dextran と混和静置して得られた leukocyte rich plasma を前記 PBS で洗浄後, Ficol-

Fig. 1 Experimental procedures for leukocyte function in urine

Heparinized blood

$\downarrow \leftarrow$ Add $6 \%$ dextranized saline

Standing for 1 hour at R.T.

1

$\mathrm{cfg}$, at $1000 \mathrm{rpm}$ for $10 \mathrm{~min}$

1

Wash with PBS, pH 7.2

$\perp$

Ficol-Hypaque gradient

$\downarrow$

cfg, at $1500 \mathrm{rpm}$ for $20 \mathrm{~min}$

$\downarrow$

Wash with PBS, $\mathrm{pH} 7.2$

$\leftarrow$ Add $0.2 \% \mathrm{NaC}$

- Add $1.6 \% \mathrm{NaCl}$

Wash with PBS, pH 7.2

$\underset{0.3 \mathrm{~m} \ell \text { of } 10^{6} \text { cells } / \mathrm{m} \ell}{\text { PMN in PBS }}+\frac{1}{2.4 \mathrm{~m} \ell}+\frac{\text { Urine }}{0.3 \mathrm{~m} \ell \text { of } 10^{7} \text { cells } / \mathrm{m} \ell}$

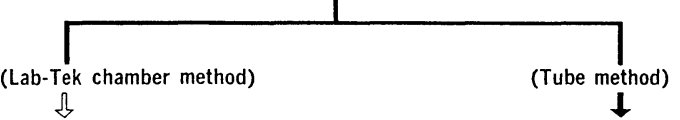

$\Omega$

Mix

b)

Pour $0.2 \mathrm{~m} \ell$ each into

Lab-Tek chamber

I

Incubate at $37^{\circ} \mathrm{C}$ for $30 \mathrm{~min}$ is

Decantation

\&

Fix with absolute methanol \&

Giemsa stain

إ

Examine microscopically $(\times 1000)$

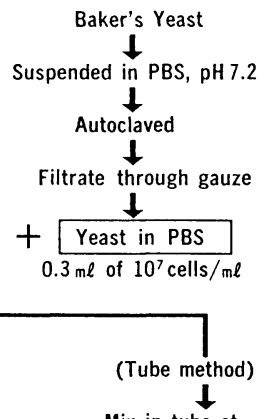

Mix in tube at

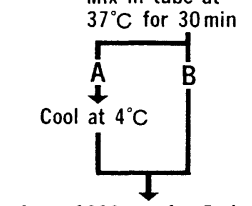

cfg at $1000 \mathrm{rpm}$ for $5 \mathrm{~min}$

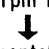

Decantation

$\leftarrow \begin{gathered}\text { Add } 0.01 \% \\ \text { fuchsin }\end{gathered}$

Examine microscopically $(\times 400)$ 
Hipaque に重層し遠沈した。最下層をPBS で洗浄後, 低張食塩水処理して赤血球を溶血させ，PBS で洗浄 後, $0.25 \%$ trypan blue で生細胞率を測定し, 最終的 に多核球を $1 \times 10^{6} \mathrm{cell} / \mathrm{s} / \mathrm{ml}$ 含むようにPBS で濃度調 節した。

パン酵母はPBS に浮遊させオートクレーブにかけ た後, ガーゼで濾過し, 最終的にパン酵母を $1 \times 10^{7}$ cells $/ \mathrm{ml}$ 含むようにPBS で濃度調節した。

尿については, 正常人とUTI 患者から得られた尿を 直ちにミリポアフィルター $(0.45 \mu)$ にかけた後, 実験 まで冷凍保存した。 以上の実験操作は Fig. 1 に示し た。

組織内もしくは尿路上皮に付着した多核球の細菌貪 食を模した実験系としては Lab-Tek chamber （Miles）を用いた。これは多核球と酵母が混入された 尿懸濁液を，周囲がプラスチックの壁で囲まれたスラ イドグラスの上に注ぎ，ガラス面に付着させた多核球 の酵母貪食を検討するもので, Wright 染色して顕微 鏡下 $(\times 1,000)$ に貪食率を測定した。

Tube A 法と Tube B 法は共に多核球と酵母を尿中 に浮遊させ， 4 〜分毎にタッピングして尿路腔にお ける多核球の細菌貪食を模したものであるが, Tube B 法は $\mathrm{A}$ 法での酵母貪食を停止させる $4{ }^{\circ} \mathrm{C}$ 冷却操作を 行わず, 直ちに 1,000 回転, 5 分間遠沈し, 酵母と多核 球の接触機会を増加させた系である. Tube 法では沈 查を wet-mount して400倍で検鏡して貪食率測定を行 らため, 細胞内の酵母と細胞外の酵母とが判然としに くいので, $0.01 \%$ fuchsin を滴下して細胞外の酵母は 赤染されるようにした。使用した尿は正常人 2 名の尿 と尿路感染症患者の尿で, コントロールとしては0.067 M PBS, pH 7.2 と Hanks Balanced Sault Solution (HBSS) $\mathrm{pH} 7.2$ を用いた。

4. UTI 患者の尿中の白血球の透過型電子顕微鏡 （TEM）を用いた観察

（1）各疾患群に打ける尿沈査の TEM 像

$\mathrm{APN}$ 患者 1 名, $\mathrm{AC}$ 患者 3 名, CPN 患者 4 名, CC 患者 3 名についてそれぞれの尿沈查の TEM 標本を作 製し, 尿中の白血球の細菌貪食状態と, 細胞小器管の 微細構造を観察した. 同時に, Wright 染色した光顕標 本も作製した。

（2）尿路感染症患者の尿中の白血球の latex 粒子貪 食能

$\mathrm{AC}$ 患者 1 名, $\mathrm{CC}$ 患者 1 名, $\mathrm{CPN}$ 患者 2 名のそれぞ れの尿を 1,000 回転 10 分間遠沈し, 上清を適量除き, 白
血球数が $5 \times 10^{5} \mathrm{cells} / \mathrm{ml}$ となるように調節し, latex 粒 子（Bacto-Latex 0.81 ; Difco）を充分量（latex/白血 球 $\fallingdotseq 100)$ 滴下し, $37^{\circ} \mathrm{C} 30$ 分間培養した後, 沈査を TEM 観察した。

（3）無菌性膿尿中の白血球の Escherichia coli 貪食 能

温水ブレオマイシン療法を行つている膀胱癌患者の 無菌性膿尿（尿浸透圧 $349 \mathrm{mOsm} / \mathrm{L}$ ，尿 $\mathrm{pH} 7.0$ ）を 1,000 回転 10 分間遠沈し, 上清を適量除き, 白血球数 $5 \times$ $10^{5}$ cells $/ \mathrm{ml}$ とし, これに, Brain-Heart infusion 培地 (日水) で $37^{\circ} \mathrm{C} 24$ 時間増菌された臨床分離 E. coli 前 記 PBS で 3 回洗浄後, 充分量 (E. coli/白血球 $\fallingdotseq 100)$ を加光， $37^{\circ} \mathrm{C} 30$ 分間培養した。同様に沈查を TEM 観 察した。

\section{（4） TEM 標本製作法}

沈査に $10 \%$ acrolein を注入し， $4{ }^{\circ} \mathrm{C} 60$ 分間固定し, $0.1 \mathrm{M}$ PBS, $\mathrm{pH} 7.4$ で洗浄後, $1 \%$ osmium で $4{ }^{\circ} \mathrm{C} 2$ 時間固定した。次いで型の如く ethanol 系にて脱水し, 酸化プロピレン置換後, Epon 812に包埋した. ultramicrotome にて超薄切片を採取し, ウラン, 鉛による二 重染色後, Hitachi H500にて観察した。

\section{IV. 成 績}

\section{1. 尿中の白血球の生存確認に関する予備的検討}

(1) 生存率の検討方法

Fig. 2 Survival rate of urinary leukocytes determined by various stains

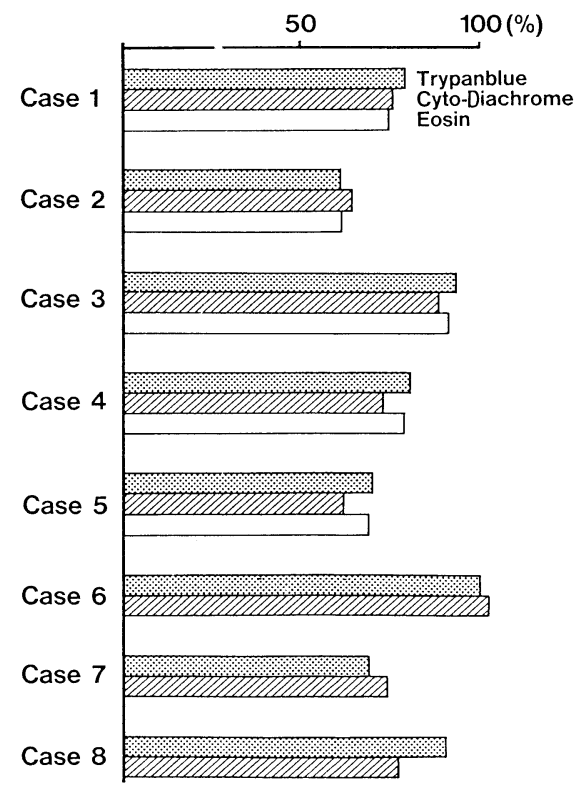


3 つの異なる染色液のいずれを使用してもほぼ近似 した値が得られた（Fig. 2).

（2）経時的生存率変動

低浸透圧尿中の白血球が高浸透圧尿中のものに比し ややdark-stained cell と pale-stained cell の割合が 早期に増加し, 細胞の viability 維持，保存に不適であ ると思われた。な抏, $768 \mathrm{mOsm} / \mathrm{L}$ 以上の高浸透圧尿の colorless cell には glitter cell はほとんど存在してお らず, $484 \mathrm{mOsm} / \mathrm{L}$ 以下の colorless cell には glitter cell の割合が高かつた. しかし，いずれにしろ 2 時間以 内は生存率に及ぼす影響は無視できるほど軽微なもの であつた（Fig. 3).

（3）温度の生存率に及汸す影響

2 時間の検討では $25^{\circ} \mathrm{C}$ と $37^{\circ} \mathrm{C}$ の温度による生存率の 差はほとんどなく，末た生存率も直後尿の生存率と汪 ぼ等しかつた (Fig. 4).

(4) 小括

上記の結果から UTI 患者の尿中の白血球の生存率 の測定は, 膀胱内蓄尿時間が 2 時間以内のものとし, 不明の場合には排尿量が $100 \mathrm{ml}$ 以下であれば膀脱内蓄 尿時間は 2 時間以内とみなして, 採尿後は遅くとも 1 時間以内に， $0.25 \%$ trypan blue 使用して行うこと とした。

Fig. 3-1 Hourly changes of survival rate (1) (Cyto-Diachrome)
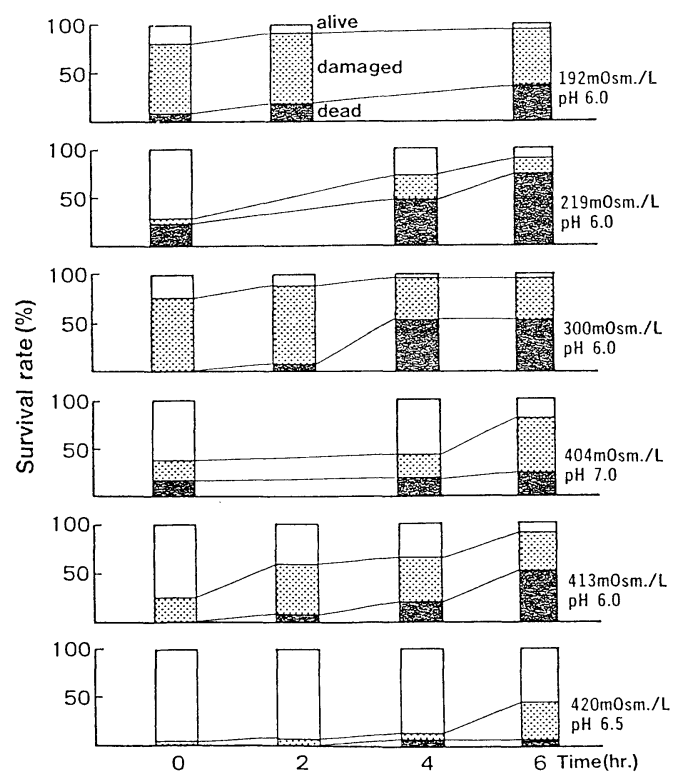

Fig. 3-2 Hourly changes of survival rate (2) (Cyto-Diachrome)

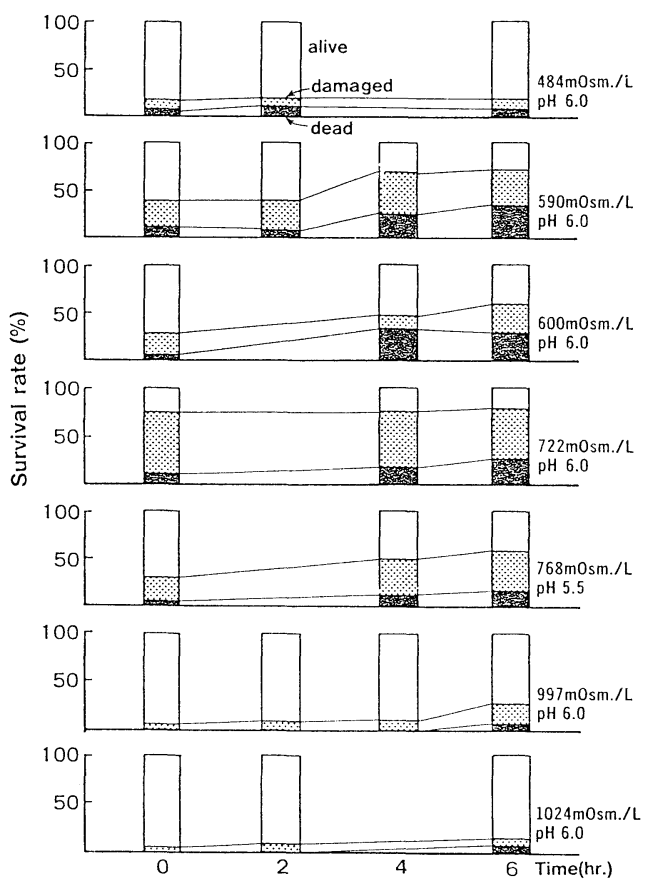

2. UTI 患者の尿中の白血球について

（1）尿中白血球の生存率

尿中の白血球の $50 \%$ 以上が尿浸透圧にかかわらず生 存して抢り, 全症例の平均生存率は $82 \pm 13 \%$ であつた (Fig. 5).

疾患別に生存率を検討すると, AC, APN, CC, CPN に扮ける平均生存率はそれぞれ $85 \pm 10 \%, 77 \pm 12 \%$ ， $79 \pm 16 \%, 84 \pm 13 \%$ で, 各疾患群の間にも, 急性の UTI と慢性の UTI との間にも,さらに上部尿路感染症と下 部尿路感染症との間にも平均生存率に有意差を認めな からた。

同様に尿 $\mathrm{pH}$ と生存率との間にも一定の傾向を認め なかつた (Fig. 6).

（2）尿中の白血球の貪食率

尿中の白血球で細菌を貪食しているものは少なから ず認められた。貪食率と尿浸透圧との関係を検討する と (Fig. 7)， $600 \mathrm{mOsm} / \mathrm{L}$ 末満の尿中の白血球の平均 貪食率は $13.8 \pm 15.4 \%$ であるが， $600 \mathrm{mOsm} / \mathrm{L}$ 以上の 場合には平均貪食率は6.5 $09.3 \%$ で有意に低値となつ ていた $(\mathrm{p}<0.01)$ ，そこで尿浸透圧を疾患別に検討し ていると, AC, APN , CC, CPN の平均尿浸透圧はそ

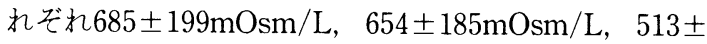


Fig. 4 Influence of temperature on survival rate of urinary leukocytes ( $0.5 \%$ trypanblue)
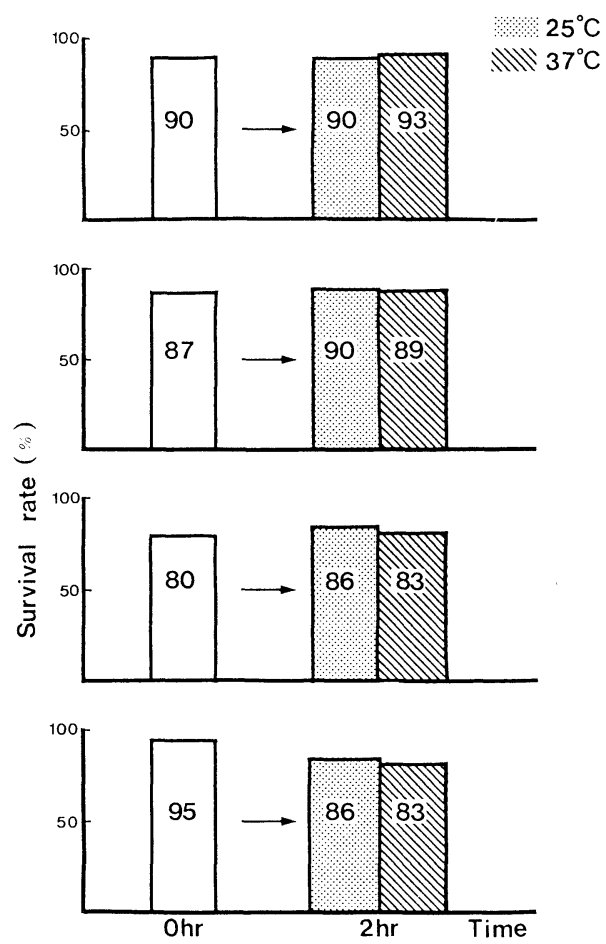

Fig. 5 Influence of urine osmolarity on the viability of urinary leukocytes

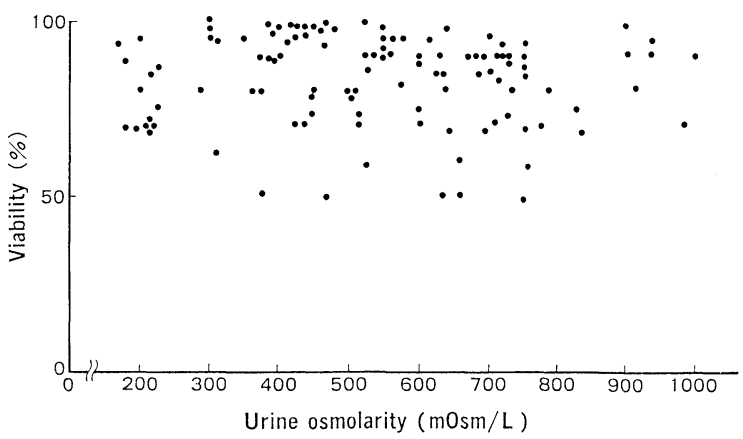

$182 \mathrm{mOsm} / \mathrm{L}, 427 \pm 160 \mathrm{mOsm} / \mathrm{L}$ で, $\mathrm{AC}$ と $\mathrm{APN}$ との 間には浸透生の有意差を認めないが，その他の各群間 には有意差が認められた（ $\mathrm{p}<0.05 ）$.

さらに, 急性の UTI では尿浸透圧が $600 \mathrm{mOsm} / \mathrm{L}$ 以 下でも, 慢性の UTI に比しその尿中の白血球の貪食率 は低値であつた。

次に貪食率を疾患別に検討すると, Fig. 8 に示す如 く, $\mathrm{AC}, \mathrm{APN}, \mathrm{CC}, \mathrm{CPN}$ の平均貪食率は，それぞれ
Fig. 6 Influence of urine $\mathrm{pH}$ on the viability of urinary leukocytes

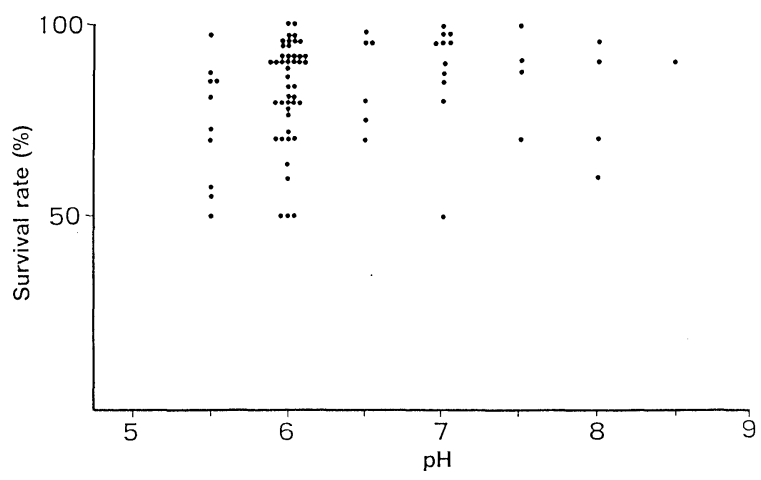

Fig. 7 Urine osmolarity and rate of phagocytosis of urinary leukocytes

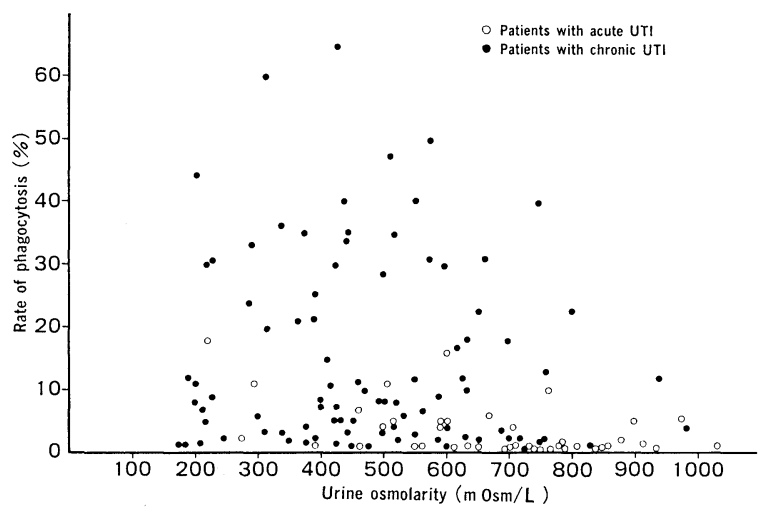

$3.0 \pm 4.1 \%, 2.1 \pm 1.8 \%, 13.2 \pm 13.6 \%, 18.3 \pm 15.2 \%$ であつた， AC と APN の群間，および CC と CPN の 群間には貪食率に有意差を認めず，また下部尿路感染 症と上部疗路感染症との間にも有意差を認めなかつ た。そこで急性と慢性に分けて検討してみると，急性 の UTI は平均貪食率が $2.8 \pm 3.7 \%$ で，慢性のUTIの 平均貪食率 $15.2 \pm 14.4 \%$ に比し有意に低值であつた $(\mathrm{p}<0.01)$.

カテーテル留置の有無とその尿中の白血球の貪食率 との関係について，まずCCについて検討すると，

Table 2 に示す如く, カテーテル留置群の平均貪食率

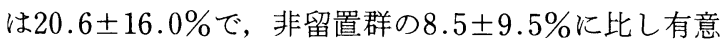
に高值である $(\mathrm{p}<0.01)$. しかし，カテーテル非留置 $\mathrm{CC}$ 群です, $\mathrm{AC}$ の平均貪食率 $3.0 \pm 4.1 \%$ に比べると有 意に高值である $(\mathrm{p}<0.01)$. 同様に $\mathrm{CPN}$ について検討 すると, カテーテル留置の CPN 群は非留置 CPN 群よ り有意に貪食率が高い $(\mathrm{p}<0.01)$. しかし, 非留置 
Fig. 8 Rate of phagocytosis of urinary leukocytes from patients with UTI and antibody-coated bacteria

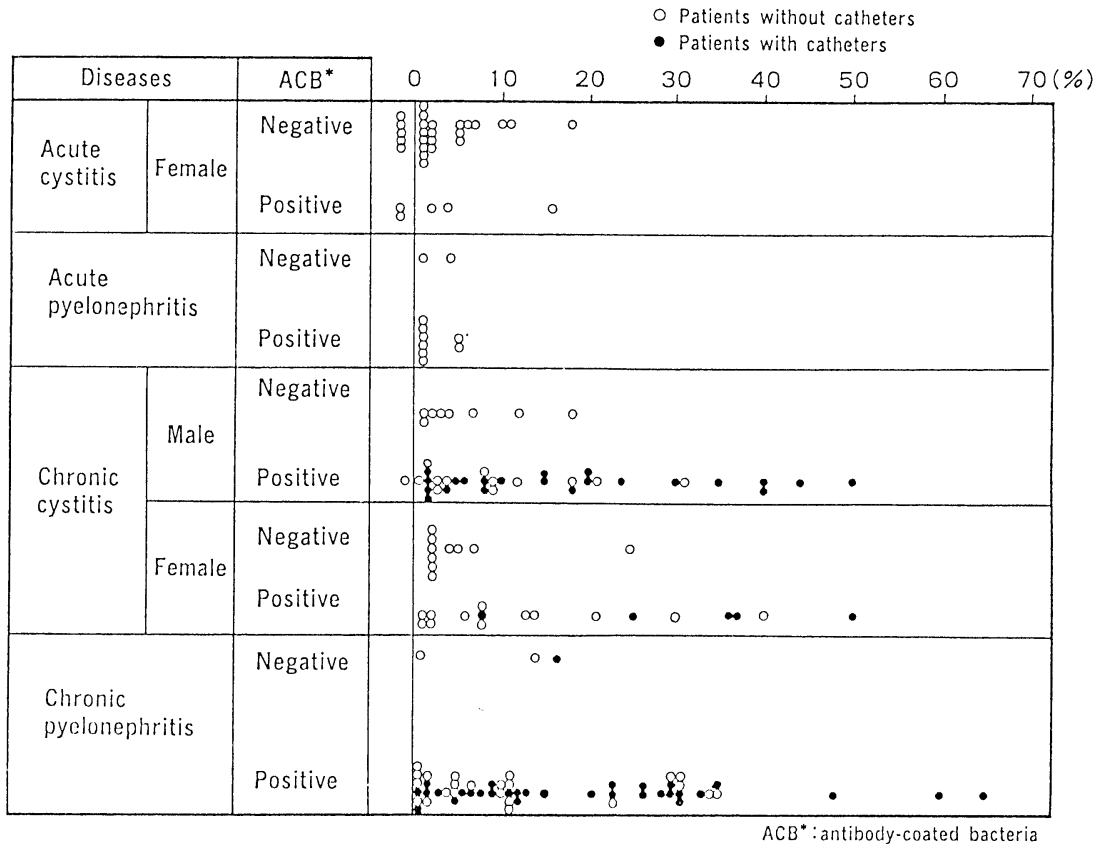

Table 2 Influence of catheter and antibody-coated bacteria on the rate of phagocytosis

\begin{tabular}{|c|c|c|c|c|}
\hline \multirow{2}{*}{ Diseases $\underbrace{\text { Catheter \& }}_{\text {ACB }}$} & \multicolumn{2}{|c|}{ catheter not indwellt } & \multirow{2}{*}{\multicolumn{2}{|c|}{ 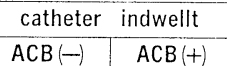 }} \\
\hline & $\mathrm{ACB}(-)$ & $\mathrm{ACB}(+)$ & & \\
\hline \multirow{2}{*}{ Acute cystitis } & $3.2 \pm 4.4$ & $2.0 \pm 2.0$ & & \\
\hline & \multicolumn{2}{|c|}{$3.0 \pm 4.1$} & & \\
\hline \multirow{2}{*}{$\begin{array}{l}\text { Acute } \\
\text { pyelonephritis }\end{array}$} & $*$ & $2.0 \pm 1.9$ & & \\
\hline & \multicolumn{2}{|c|}{$2.1 \pm 1.8$} & & \\
\hline \multirow{2}{*}{ Chronic cystitis } & $5.6 \pm 6.5$ & $10.7 \pm 10.7$ & & $20.6 \pm 16.0$ \\
\hline & \multicolumn{2}{|c|}{$8.5 \pm 9.5$} & \multicolumn{2}{|c|}{$20.6 \pm 16.0$} \\
\hline \multirow{2}{*}{$\begin{array}{l}\text { Chronic } \\
\text { pyelonephritis }\end{array}$} & $*$ & $12.8 \pm 11.4$ & $*$ & $22.8 \pm 16.6$ \\
\hline & \multicolumn{2}{|c|}{$12.4 \pm 10.8$} & \multicolumn{2}{|c|}{$22.8 \pm 16.6$} \\
\hline
\end{tabular}

$\mathrm{CPN}$ 群でも，APN と比べると有意に高值であつた $(\mathrm{p}<0.01)$. 以上よりカテーテルの存在は貪食率に影 響を与える最大の原因で,ついで慢性のUTIをひきお こす内因性の原因（結石, 腫瘍, 前立腺肥大症, 神経 因性膀胱など）も関連するものと思われた。

尿中細菌の菌数と尿中の白血球の貪食率との関係を 検討すると (Fig. 9), 急性の UTI では菌数にかかわら ず貪食率は $10 \%$ 以下のものが臣とんどで，菌数と貪食 率との相関は認められなかつた。しかし，慢性の UTI では $10^{4}, 10^{5}$ ，㧊よび $10^{6}$ cells $/ \mathrm{ml}$ の各々と $10^{7}$ cells $/ \mathrm{ml}$ との間に $(\mathrm{p}<0.05)$, さらに $10^{4}$ cells $/ \mathrm{ml}$ と $10^{5} \mathrm{cells} / \mathrm{ml}$ との間にも $(\mathrm{p}<0.05)$ 平均貪食率について有意差が認
Fig. 9 Correlation between bacterial count and rate of phagocytosis

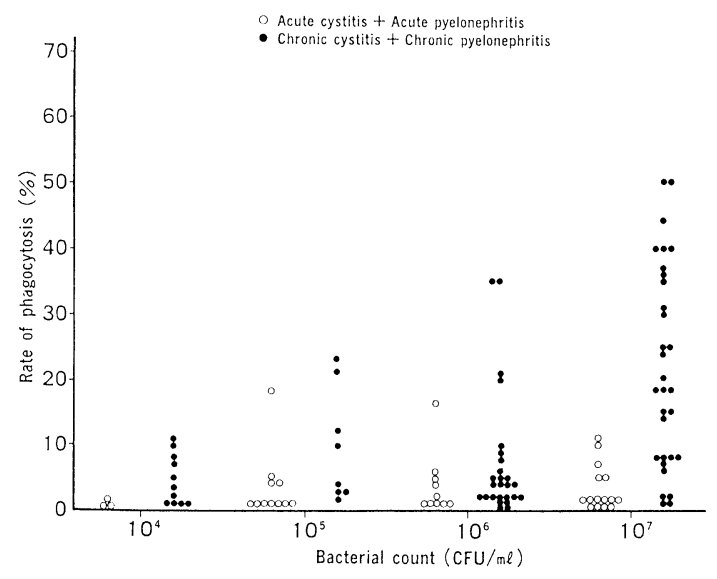

められ，菌数と貪食率との間に正の相関が伺えた。な お慢性のUTI と急性のUTI との間に菌数分布の差は 認められなかつた。

尿 $\mathrm{pH}$ と尿中の白血球の貪食率との関係は（Fig. 10), に示す如く, 急性の UTI では 1 例が $\mathrm{pH} 7.0$ であ つたが，他は全て pH 6.5以上であつた。一方，慢性の UTI では pH 7.0 以上の症例が $24 \%$ (25例) 存在してい た. 慢性症について $\mathrm{pH} 7.0$ 以上の平均貪食率は19.0土 
Fig. 10 Correlation beiween urinary $\mathrm{pH}$ and rate of phagocytosis

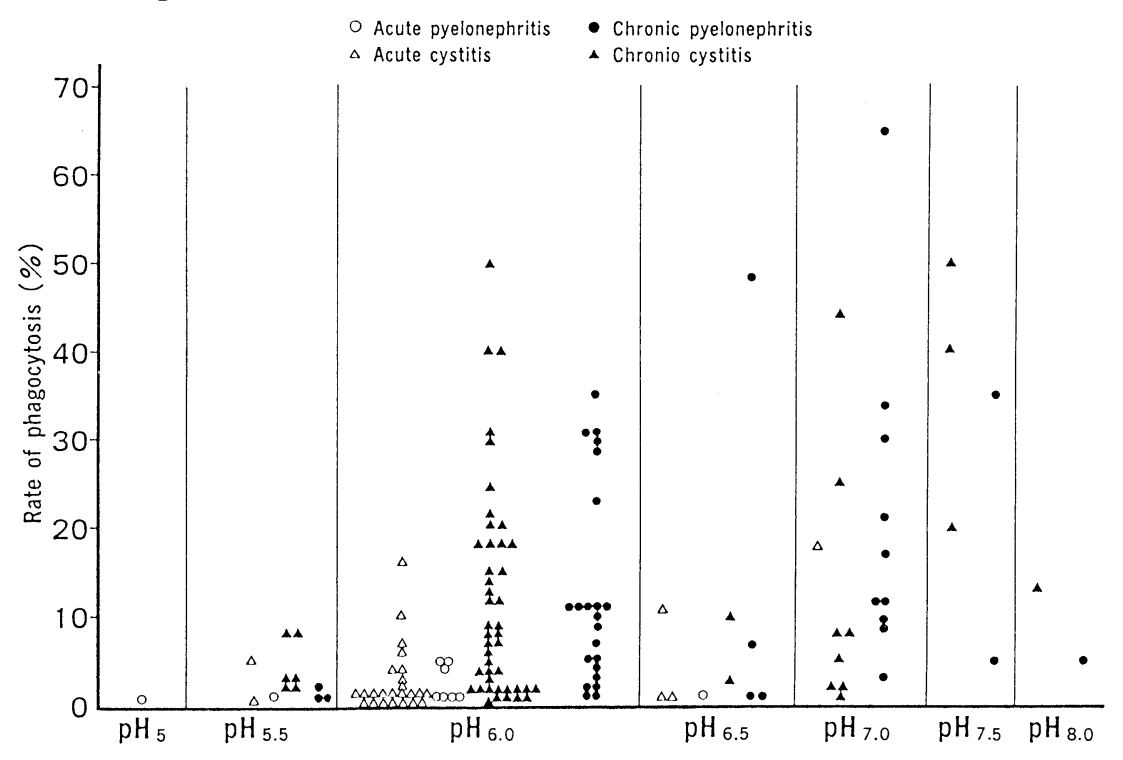

$17.2 \%$ で, $\mathrm{pH} 6.5$ 以上の平均貪食率 $11.3 \pm 11.9 \%$ より 有意に高値であつた $(\mathrm{p}<0.05)$.

尿中の白血球の中で好中球の占める割合についての 検討は, 標本が血液塗抹標本のように均一とはならず, また染色をWright 染色でのみ行つたため，厳密な白 血球分類は不可能であり，全例については施行してい ないが，25例について検討した結果では，90\%程度が 好中球で占められていた。 な抢，急性のUTI では好中 球の占める割合が $90 \%$ 以上と高く, 慢性の UTI でも細 菌の菌数が多いものではやはり好中球が $90 \%$ 程度を占 めるが，菌数の比較的少ないものでは単核球様細胞の 占める割合の高いものも散見され，又，尿管皮膚瘦患 者の 1 例では好中球が $50 \%$ 程度を占めていた。

(3) $\mathrm{ACB}$

$\mathrm{ACB}$ の陽性率を疾患別に検討してみると, AC, APN, CC, CPN の順に $16.7 \%, 80.0 \%, 73.9 \%, 93.8 \%$ で $\mathrm{AC}$ に新いて有意 $(\mathrm{p}<0.01)$ に低率とはい光, $\mathrm{ACB}$ が上部尿路感染症に特異的なものとは言えなかつた。 さらに, CCについてみると, カテーテル留置例では全 例が $\mathrm{ACB}$ 陽性となり, カテーテル非留置例でも $58.1 \%$ の症例が陽性であつた，前立腺炎合併の可能性 を検討するため，性別に分けてカテーテル非留置 CC 例について ACB の陽性率を比較すると, 男性では $61.9 \%$ (13例/21例)，女性では $54.5 \%$ (12例/22例) と 有意差は認められず，前立腺炎の合併による $\mathrm{ACB}$ 陽 性という可能性は否定的であり, 自他覚的所見でも前
立腺炎の合併していると推定される症例は含まれてい なかつた。

次に ACB と貪食率との関係について検討した。 ずCCについてみると, ACB 陰性群(全例カテーテル 非留置例）の平均貪食率は, $5.6 \pm 6.5 \%$ で, 陽性群の 平均貪食率15.8 $14.5 \%$ に比し有意に低值である $(\mathrm{p}<0.01)$. しかし， ACB 陽性群にはカテーテル留置 例が多いため，これを除いたカテーテル非留置 $\mathrm{ACB}$ 陽性群の平均貪食率, $10.7 \pm 10.7 \%$ と比較すれば, $\mathrm{ACB}$ 陰性群は貪食率が低いという傾向（ $\mathrm{p}=0.0798 ）$ は認めるものの有意差とは言えない(Table 2). さら に, $\mathrm{ACB}$ 陽性の CC や CPN の症例の中では, 貪食率 は高いものから低いものまで種々であり, 又, $\mathrm{ACB}$ 陽 性の APN の平均貪食率 $2.0 \pm 1.9 \%$ ACB 陰性の $\mathrm{AC}$ の平均貪食率 $3.2 \pm 4.4 \%$ と有意差を認めず, $\mathrm{AC}$ に ついても $\mathrm{ACB}$ 陽性群と $\mathrm{ACB}$ 陰性群で貪食率の有意 差を認めなかつた。 以上の如く $\mathrm{ACB}$ のオプソニン効 果は今回の検討では明らかではなかつた。

\section{3. 尿中でのヒト多核球のパン酵母領食能の実験的} 検討

健康成人の末梢血より得た多核球の Lab-Tek chamberのガラス面に付着した密度を光顕標本で観 察すると, 少なくとも $800 \mathrm{mOsm} / \mathrm{L}$ までは尿浸透圧に よる变化は認められず，また付着している多核球の酵 母の貪食率を正常尿, 急性打よび慢性の尿路感染尿, HBSS, PBS について観察すると,いずれについても 
15 40\%で浸透圧にかかわらずほぼ一定した值を示し た (Fig. 11).

tube 内に招いて浮遊状態に打ける多核球の酵母貪 食能を検討すると (Fig. 12)，尿浸透圧が $600 \mathrm{mOsm} / \mathrm{L}$ を超える尿中では高くても $1 \%$ 以下の貪食率でしかな く，また $600 \mathrm{mOsm} / \mathrm{L}$ 以下でも貪食率が $5 \%$ 以下のも

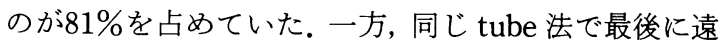
沈させ，酵母と多核球を密に接触させた系 (Fig. 13) では, 尿浸透圧が $600 \mathrm{mOsm} / \mathrm{L}$ 超えるとやはり正常 尿, 感染尿とも貪食率は高くても $1 \%$ 以下であつたが, $600 \mathrm{mOsm} / \mathrm{L}$ 以下では著明に貪食率が充進して招り, 正常者 2 名の貪食率の検討で明らかなように, 200 400mOsm/L の尿中でとくに貪食率が高値とな

Fig. 11 Opsonic effect of normal and infected human urine on phagocytosis of yeasts by neutrophils (Lab-Tek chamber method)

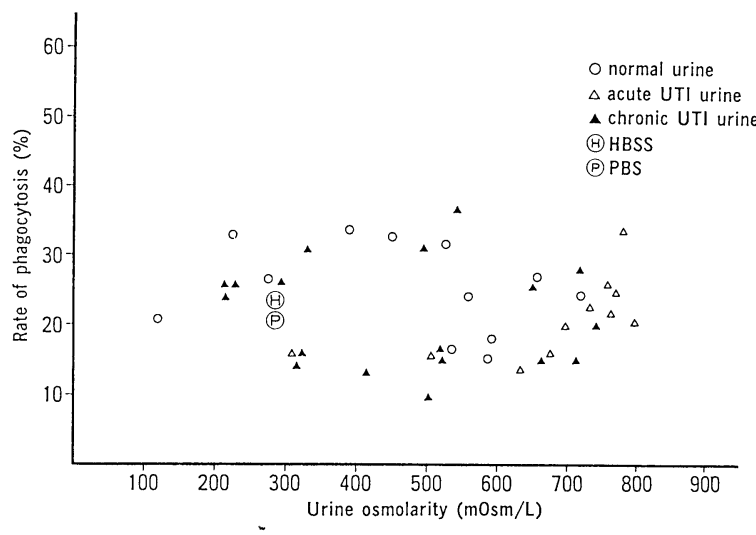

Fig. 12 Opsonic effect of normal and infected human urine on phagocytosis of yeasts by neutrophils (Tube method-A)

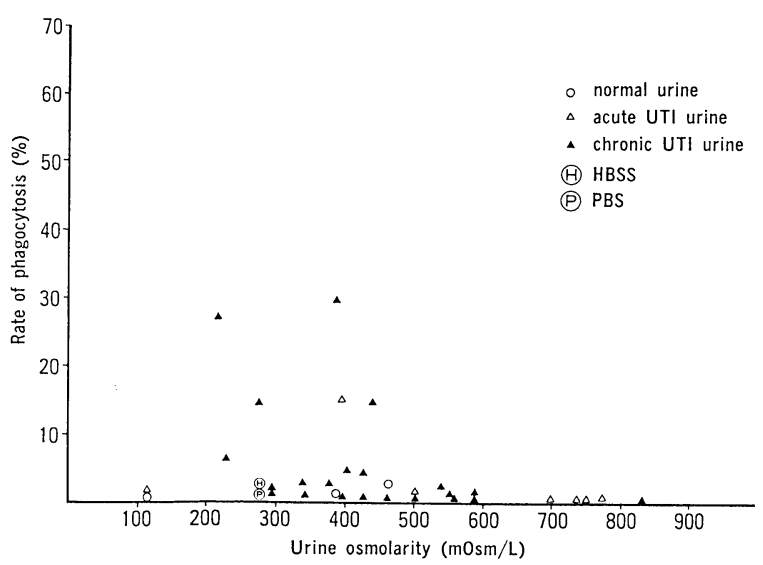

Fig. 13 Opsonic effect of normal and infected human urine on phagocytosis of yeasts by neutrophils (Tube method-B)

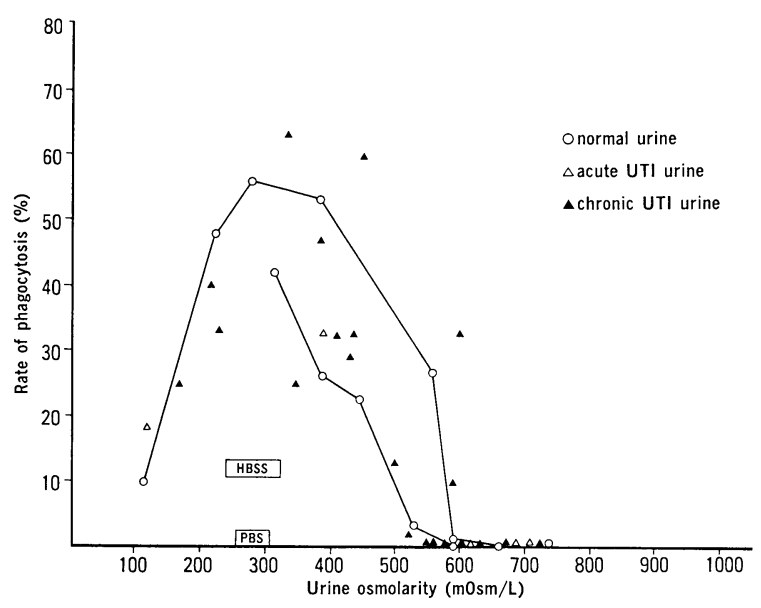

つた。

tube 法に打ける尿中での貪食率をHBSS, PBS と 比較すると，尿中でむしろ高い貪食率が示された。し かし, 慢性尿路感染症の尿と正常尿との間には貪食率 の差は認められなかつた。急性尿路感染症で尿浸透圧 が $600 \mathrm{mOsm} / \mathrm{L}$ 以下の症例は少なかつたため，急性尿 路感染症の尿と正常尿との貪食率に及ぼす比較は困難 であつた。

\section{UTI 患者の尿中の白血球の TEM を用いた観察}

(1) 各疾患群に打ける尿沈査の TEM 像

Wright 染色では貪食されて多核球に取り込まれた 細菌と, 細胞表面に粘着している細菌を厳密に区別す ることはかなり困難であるが，TEM では容易であつ た。一方, TEM では得られた画面は限られた部分の, しかも切断面であるので正確な貪食率を計算すること はできないが，注济近似した值が推定された。

Fig. 14は APN 症例で Escherichia coli が $10^{6}$ cells/ $\mathrm{ml}$ 証明された排尿直後の新鮮尿の TEM 像であり, 貪 食の認められない好中球では細胞質内に 1 次顆粒や 2 次顆粒が多数存在し, 核構造も保たれ, 形態的には血 中の好中球と同様でありほとんど障害を受けてないも のと思われた。この症例では TEM 上，ほとんどの白 血球は細菌を貪食して打らず,写真はE. coliを貪食し ていると考兄られる数少ない白血球の一つが示され， 顆粒の多くは内容が失なわれ空胞状となり, 細胞質も 架状構造を呈している. 同時に行つた光顕標本でも $1 \%$ \%か貪食は認められなかつた。 
Fig. 14 Transmission electron microscopic finding of freshly obtained urinary leukocytes in patient with acute pyelonephreitis $(\times 7,700)$.

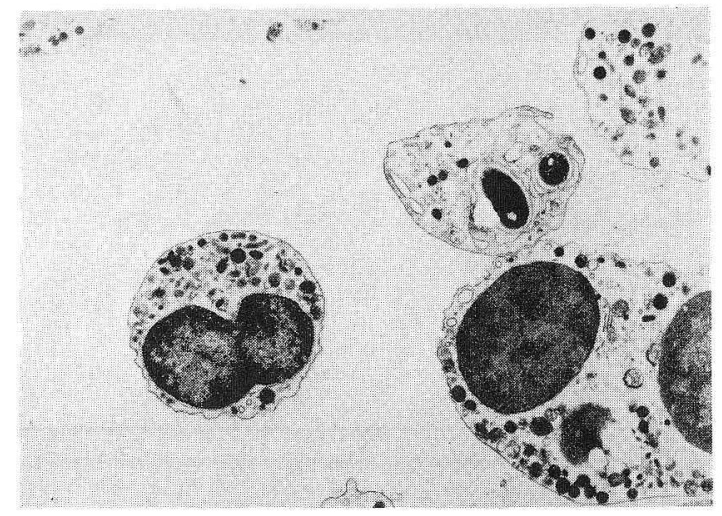

Fig. 15は AC 症例で, E. coli が $10^{6} \mathrm{cells} / \mathrm{ml}$ 証明さ れ， $4{ }^{\circ} \mathrm{C}$ で 4 時間保存された尿の TEM 像である。白 血球の顆粒や，ミトコンドリアその他の細胞小器管は 崩壊消失し，核構造もはつきりしなくなり，細胞質模 も崩壊しかけている。すでに崩壊した白血球の遺残物 も周囲に多数散見される。E. coliを貪食しているもの は少数散見されるのみであつたが，写真は数少ない貪 食が認められたものを示した。光顕標本での貪食率は $3 \%$ \%つた。

Fig. 16はカテーテル留置尿管皮膚瘦患者の新鮮尿
Fig. 15 Transmission electron microscopic finding of urinary leukocytes in patient with acute cystites cystites. This urine specimen was stored at $4^{\circ} \mathrm{C}$ for 4 hours $(\times 7,700)$.

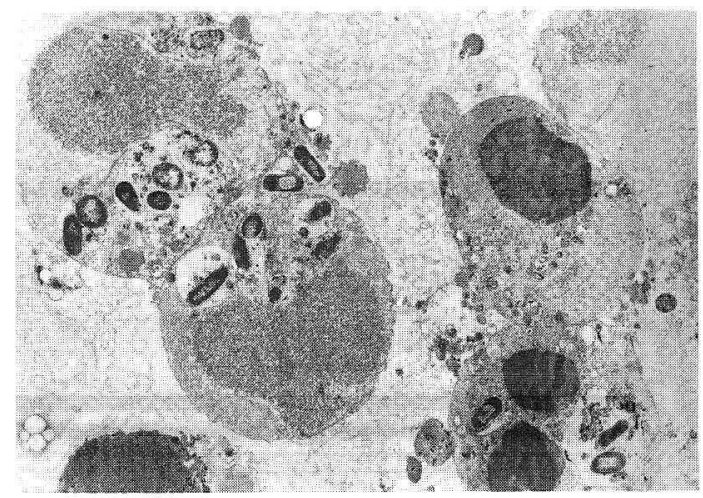

の光顕標本と TEM 像である. 過半数の尿中の白血球 の細胞内には多数の細菌が貪食されて扣り, 顆粒や細 胞小器管は汪とんど消失し, 細胞質は泡沫状構造を呈 しているが，核構造のみは未だよく保たれている。光 顕標本での貪食率は60\%であつた.

カテーテル留置のCC 患者の新鮮㽷の光顕像と TEM 像は CPN 症例の Fig. 16 之同様な所見であつ た.

以上の光顕像と電顕像との比較検討から, 尿中の白 血球の細菌頜食率は光顕標本が美しく仕上げれば充分

Fig. 16 Microscopic finding of freshly obtained urinary leukocytes in patient with ureteral indwelling catheter.

Left side shows light microscopic finding $(\times 1,000)$ and right side is transmission electron microscopic one $(\times 7,700)$.
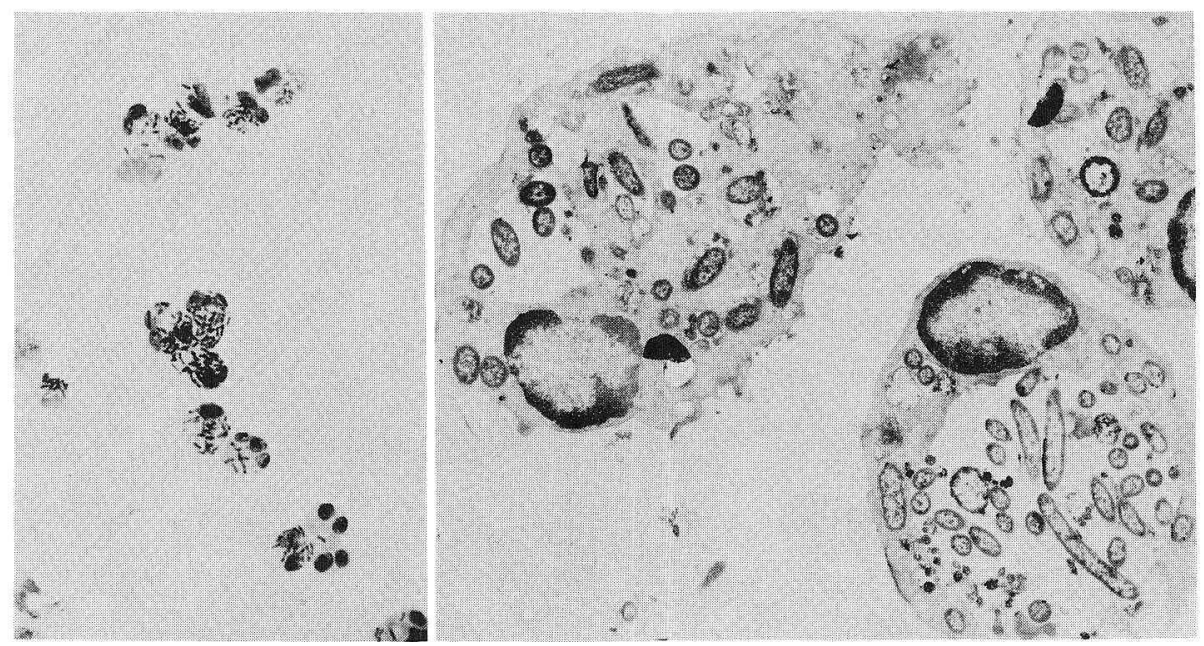
信頼に足るものであることが確認された。, 又, 尿路腔 へ遊出し膀胱内貯留時間が 2 時間以内の細菌を貪食し ていない白血球は，排尿直後では形態的にはほとんど 障害されていないが, 細菌を貪食した白血球では顆粒 の消失や細胞質の变性が認められた。 そして保存の時 間経過とともに細胞の変性, 崩壊がさらに進んでいく ことが TEM 観察で確認された。

(2) UTI 患者の尿中の白血球の latex 粒子貪食能 TEM 観察上, AC 患者では $2 \%, \mathrm{CC}$ 患者では $3 \%$, $\mathrm{CPN}$ 患者では $4 \%$ 尿中の白血球がその尿中で latex 粒子を貪食した，Fig. 17は CPN 患者の TEM 像であり, latex 粓子が好中球の貪食空胞中に存在し, 領食空胞の周囲に顆粒が集合している。

Fig. 17 Transmission electron microscopic finding of neutrophils phagocytizing latex partcles in vitro $(\times 20,000)$.

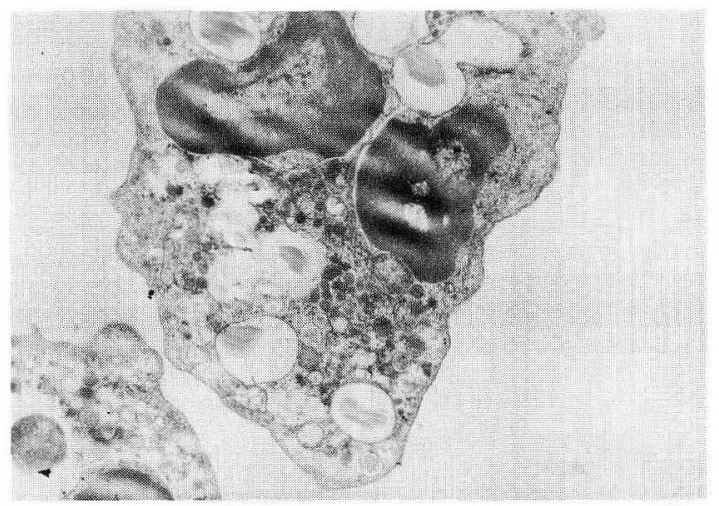

（3）無菌性膿尿中の白血球の E. coli 食食能 TEM 観察上, $3 \%$ 程度の白血球が E. coli ていることが確認された(Fig. 18). 細胞質基質が全般 的に絮状化している像が示されている。

以上の実験で，膀胱腔での貯留時間に加えて実験に 供されるまでの操作時間が経過している尿中の白血球 が，その尿中でな拈 latex 粒子や E. coli 貪食するこ とから，尿路上皮から尿路腔へと遊出した白血球は早 期には尿中で充分細菌を貪食する可能性が示された。

\section{V. 考 按}

尿の白血球（とくに多核白血球）の機能に対する抑 制効果については多くの報告1)3方あり，高浸透圧，血 清成分の欠如, $\mathrm{pH}$ の低值が主たる原因之考光られて きた. Bryant ${ }^{3}$ は血清無添加の実験系で, 血浆中での多 核白血球機能を対照とすると，正常尿中では浸透圧に かかわらず遊走, 付着, 凝集, 貪食が汴济消失し, 高 張尿はとくにこれらの機能を抑制すると報告した。一 万, 血清でオプソナイズ処理された細菌の貣食率は, 尿中 (pH 5.6,477mOsm/L) でも血浆中之同等であつ たと報告し, CPN 時の尿中抗体や尿中補体の存在の可 能性や，蛋白尿の合併や多尿時にはわずかではあろう が尿中の白血球機能の増強の可能性を示唆している. しかしこれらも現実には無視できる程度であろうと結 論している。また, Knoll ら9は kkin window 法による in vivo 実験で正常人の高浸透圧尿が白血球の遊走, 貪 食を抑制することを証明し，このために腎盂腎炎が発 症しやすいのではないかと考按している。

Fig. 18 Transmission electron microscopic finding of neutrophils phagocytizing Escherichia coli in vitro $(\times 37,500)$.

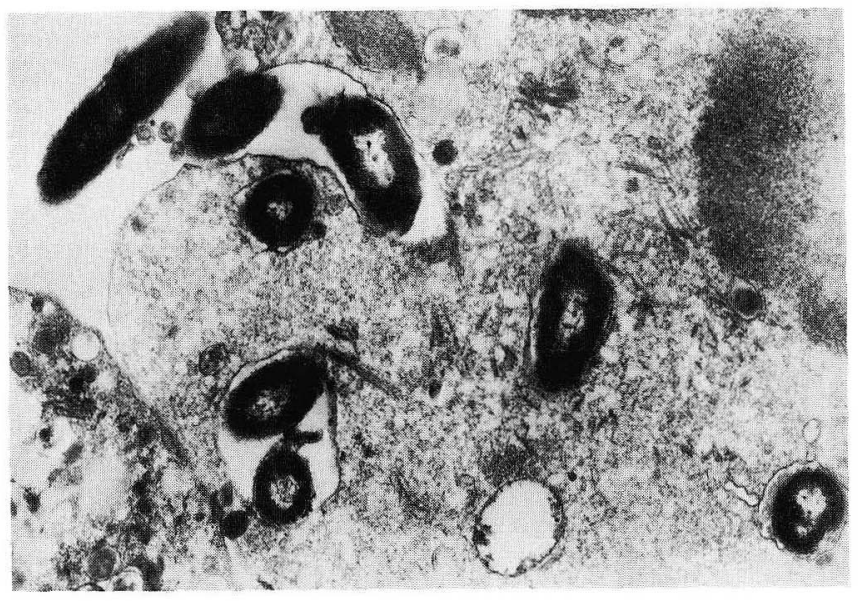


一方，最近になつて実験的検討であるが，Fukushi $ら^{4)}$ や西村 $5^{5)}$ の尿中の白血球の貪食能の存在を示す 成績, さらに末梢血の多核球について, AC 患者尿中で は浸透圧が200 $500 \mathrm{mOsm} / \mathrm{L}$ であれば，PBS 中で $E$. coli や酵母を貪食させた場合よりも高い貪食率が得ら れたとする実験成績の報告 ${ }^{10)}$ ぬみられる。

しかし，これらの成績は末梢血中の多核球について の検討，あるいは動物に打ける実験的検討である。そ こで著者は, まずUTI患者の尿中の白血球が感染症と いう環境の中でどの程度生存しているものかを検討 し, ついでその白血球が感染尿中で細菌の貪食という 機能を果して有しているものか否かを検討した。実際 に臨床的にUTI 患者の尿中の白血球のその尿中に掠 ける細菌貪食能を検討したものは本報告が最初かと思 われる。 また実験的検討として，末梢血多核球や正常 尿を使用し,さらにUTI 患者の尿中の白血球や感染尿 を使用し，血清無添加の実験系でできる限り現実に即 するようにして検討を行つたが，これらの観察結果拉

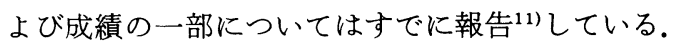

まず尿中の白血球の生存率に関して, 従来の報告に もみられる如く，尿中は生存環境としては血液中に比 し不都合と考学られるが，もし時々刻々と早急に生存 率が低下するのであれば，生存率の測定は膀胼内蓄尿 時間を可及的に短くし，採尿後もすみやかに測定しな ければならない。この生存率の時間的経過を確認する 目的で予備実験が行われたが，少なくとも膀胼内貯留 時間が 2 時間以内では变化はなく, 採尿後も 1 時間以 内であれば生存率の判定に支障がないるのと判明し た. 生存率測定のための染色法としては, eosin, Sternheimer 染色液, trypan blue いずれもほぼ近似した成 績であることを確認したので, 以後は最も一般的に viabilityを検討するに用いられている trypan blue 使用した。な技，市販の Sternheimer 染色液である Cyto-Diachrome 液は, 染色時の back ground がやや 污くなりやすく染色性も強いので, 手早く測定してし まわないと colorless cell が pale-stained cellへ, pale-stained cell が dark-stained cell へと移行してし ま5欠点を持つように思われた。宇佐美ら ${ }^{12)}$ は， $0.1 \%$ eosin 液と Sternheimer-Malbin 染色液でほほ等しい 生存細胞の比率が得られたと報告しているが, 今回の 検討で0.25\% trypan blue 子使用可能と考兄られた. また, 予備実験の結果, 低漫透圧尿中の方が高浸透圧 尿中より早期に生存率が低下する傾向を認めたが, Triger $ら^{13)}$ 亳浸透圧, 低 $\mathrm{pH}$ の尿は保存による白血
球の崩壊が少ないと報告している。但し, 白血球の諸 機能が尿中で発揮されやすい浸透圧や $\mathrm{pH}$ と, 細胞の viabilityを維持するに適した浸透圧や pH とは分け て考えられるべきである。

著者の $0.25 \%$ trypan blue を使用したUTI患者の 尿中の白血球の生存率は $82 \%$ であつた。これは Guthinger ら ${ }^{14)}$ が細菌培養で陽性となつた膀胱炎患者の尿 中の白血球をSternheimer染色した場合に, nonstained cell (alive cell) が75.2\%を占めたとする成績 にほぼ一致するものであるが，尿中の白血球のほとん どがな拉生存しているといら事実は誠に意外な感があ る.さらに, UTI 疾患群別でも差が認められなかつた ということも驚嘆に值する，以前には SternheimerMalbin 染色を行い, glitter cell の多寡によつて上部 尿路感染症と下部尿路感染症との区別がつけられると 言われ7), 上部尿路感染症の尿中の白血球の方が, 下部 尿路感染症のそれより生存率が高くなるように予想さ れていた。最近では, glitter cell は低調尿により生ず る好中球と総括され，Berman $5^{15)}$ は尿浸透圧が 600 $\mathrm{mOsm} / \mathrm{L}$ 以下に多いとしているが, 今回の著者の検討 では尿浸透圧については上部尿路感染症と下部尿路感 染症との間に有意差が認められているにもかかわら ず，生存率については差が認められなかつた。この原 因としては，CC と CPN の平均尿浸透圧はそれぞれ $513 \pm 182 \mathrm{mOsm} / \mathrm{L}, 427 \pm 160 \mathrm{mOsm} / \mathrm{L}$ であるが，いず れも $600 \mathrm{mOsm} / \mathrm{L}$ 以下であつたこと, $\mathrm{AC}$ と $\mathrm{APN}$ の平 均尿浸透圧はそれぞれ685 $\mathrm{mOsm} / \mathrm{L}$ で有意差がな $600 \mathrm{mOsm} / \mathrm{L}$ 以上であつた こと, そして最大の原因としては, trypan blue での生 存率は pale-stained cell の比率に相当するものである が, glitter cell は pale-stained cell の一部にすぎず, $600 \mathrm{mOsm} / \mathrm{L}$ を越える高浸透圧尿では glitter cell は 著者の観察でも著しく減少するが, pale-stained cell は漫透圧にかかわらず存在することが考兄られた。

次に貪食率の測定には美しい標本を作り, 細菌の付 着と鑑別することが必要であるが，細胞質の辺縁が明 瞭なるものを選び丹念に顕鏡し，一部については TEMによつて観察して確認した結果, 著者の行つた 方法はほぼ満足できる精度と考えられた。

貪食率ではACとAPNを合計した急性のUTIの 貪食率は低值で，CC とCPN を合計した慢性のUTI の貪食率は高値であつた。この原因を考えると，急性 のUTIでは慢性のUTIに比し尿浸透圧が有意に高 く, そのために白血球の貪食が行われにくかつたこと 
が考えられる。著者の tube 法での貪食実験でも600 $\mathrm{mOsm} / \mathrm{L}$ 以上では貪食が注济消失している。亦た，尿 の $\mathrm{pH}$ も急性の UTI で低いものが多く, 貪食に不適で あつたと考兄られる。慢性のUTI 患者は, 尿量を多め にするよう指導されていることも尿浸透圧を下げる原 因の一つ之考兄られるが，CPN については原疾患によ り髄質機能が障害され, 濃縮能の障害が起こつている ものが少なくないものと思われ，尿浸透圧が 600 $\mathrm{mOsm} / \mathrm{L}$ を越兄る症例は少なく, また, 尿の酸性化の 障害やProteus 感染による尿の $\mathrm{pH}$ の上昇なども加わ つているものと考えられる。そしてさらに重要な問題 として膀脱内蓄尿時間についてみると, 急性の UTI で は頻尿のために短く，白血球が細菌と接触している時 間も短いことが多いと考兄られる。

細菌がどこで白血球に貪食されたかという問題は重 要であるが，著者らも Fukushi ら"が報告しているよ らに，組織内で貪食されて尿路腔へ遊出したものの他 に，尿路腔内で貪食されたものがかなりの割合で存在 するのではないかと考杂ている. Fig. 7 や Fig. 13 にみ られる如く，諸条件が適当であれば，尿中の白血球は かなりの貪食率を示し, さらに, UTI 患者の膿尿に latex 粒子を注入してさえその中の白血球が僅かなが らも latex 粒子を貪食することが認められたことか ら, 白血球が尿路腔内へ遊出した早期汇は, 尿が低浸 透圧で尿中細菌も多ければ，十分尿路腔内で細菌を貪 食するものと考兄られる。ただし，ガラス面に付着さ せた実験系での成績が tube A 法での成績より高く, 尿浸透圧が $800 \mathrm{mOsm} / \mathrm{L}$ まで貪食が認められているこ と, さらに，多核球は本来偽足を出して異物を捕食す る細胞のため, 浮遊状態よりも付着状態の方が貪食し やすいのではないかと考兄られた。しかし，人工的に 振とう回数を増加させたり, 今回の実験の如く遠沈し て接触機会を増せば，貪食率は浮遊状態でも増加する ことが考兄られる。いずれにしろ，尿路腔内貪食とい ら中には白血球が尿路上皮に付着し，尿路腔に露出し た状態のものも含まれる可能性が考兄られる. Cobbs $5^{16)}$ も rat の膀胱感染実験で，膀胱粘膜の尿路腔に接 して並んだ多核球が細菌を貪食している像を示し，こ れが感染防御を行っているのではないかと考按してい る. 当教室の出口ら ${ }^{17)}$ 女 mouse 逆行性腎孟腎炎モデル の TEM 観察で.やはり組織内多核球には細菌貪食が きわめてまれなのにもかかわらず，腎孟腔内の多数の 多核球には細菌が多数貪食されていると報告してい る.
留置カテーテルや結石などの異物の存在は炎症を惹 起し，感染を誘発し存続せしめるが，異物表面での細 菌の増殖，残尿の発生，上皮細胞の機械的障害による 感染の深部進展などによつて細菌の菌数は増加し, 多 数の遊走した多核球とも密に長時間接触することにな る。従つてこれらの異物の存在する症例では, 病巣が 粘膜下程度までに限定している急性のUTI の場合よ りも，尿中の白血球の貪食率は高值となるものと考兄 られる，さらに，上皮細胞の破壊により血液中の蛋白 成分などの混入する可能性も高く，これらの補助的な 作用も否定できない。

次に ACB について検討すると，Thomas ら ${ }^{18)}$ の報 告後 $\mathrm{ACB}$ は上部尿路感染症に特異的とされたが，前 立腺炎 ${ }^{19)}$ や膀胱炎 ${ }^{20)}$ などでも $\mathrm{ACB}$ が陽性となる例 や，腎孟腎炎 ${ }^{21)}$ でも陰性となる例がかなり存在するこ とが明らかとなり，現在のところ腎孟腎炎と ACB の 関係は絶対的なものとは言えない。

我々の検討でも AC, APN, CC, CPN, の ACB 陽性 率はそれぞれ $16.7 \% ， 80.0 \% ， 73.9 \% ， 93.8 \%$ であ， CCの陽性率がかなり高い。本た，カテーテル留置の $\mathrm{CC}$ 例では全例が $\mathrm{ACB}$ 陽性であり, 安本ら ${ }^{22}$ も同様な 報告を行つている。 Riedash ら ${ }^{23)}$ は rat の膀胱内に細 菌と異物を同時に注入した場合には，21匹中19匹が $\mathrm{ACB}$ 陽性となり, 膀脱粘膜の表面は欠損し, lymphocyte や plasma cell が集合していると報告し， 膀脱粘膜にも local immune response が存在すると考 按している。ささらに, 臨床例においても膀胱癌, 膀脱 結石, 膀胼壁病変などで ACB が陽性となることを報 告 ${ }^{24)}$ している。著者の成績も全く彼等の成績と合致す るものであり, mucosal barrier が異物や種々の病変 で破壊されれば細菌が広範囲に実質組織へ侵入するこ とになり, 局所抗体産生や血中抗体の尿中への流出が 生ずるものと考觉られる。

ACB が一般的には下部尿路感染症で陽性率が低く, 上部尿路感染症で高い理由は, 膀胱粘膜上皮は $6 \sim 7$ 層々厚いため外的侵襲に強く，炎症が深部に及びにく いのに対し, 腎杯粘膜上皮は $2 \sim 3$ 層と薄く炎症が容 易に深部間質へ及び，局所抗体産生を促し $\mathrm{ACB}$ が陽 性となるものと思われる。

一般に ACB は nonspecific な免疫グロブリンの付 着ではなく, specific な抗体 ${ }^{25}$ が被覆されているとさ れるが, ACB 陽性の症例と陰性の症例とで貪食率の差 を比較することにより, 貪食作用促進のオプソニン効 果の有無について検討した。カテーテル非留置 $\mathrm{ACB}$ 
陽性 CC 群とカテーテル非留置 $\mathrm{ACB}$ 陰性 CC 群との 間では，ACB 陽性群の方が貪食率が高いという傾向 ( $\mathrm{p}=0.0798)$ は認めるものの, 有意に高いとは言光ず, $\mathrm{ACB}$ 陽性の $\mathrm{AC}$ 群と $\mathrm{ACB}$ 陰性の $\mathrm{AC}$ 群との間にも, さらに急性の尿路感染症の間での比較として, $\mathrm{ACB}$ 陽 性の APN 群とACB 陰性の AC 群との間にも有意差 を認めなかつたことから, ACB のオプソニン効果は明 らかではなかつた。これはUTIにおいてはまず尿浸透

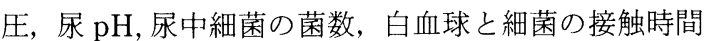
などの物理的な条件が汪とんど貪食率を規定してしま い，さらに尿中には補体が存在しないために，細菌を 特異抗体が被覆しても, 血浆中の如くにはオプソニン 効果が発揮されにくいと考光られる。しかし，Fig. 7 で示されるように貪食率が $25 \%$ を越える症例は 30 例で あり，その中の 8 例はカテーテル非留置症例であるが， 30例全例が ACB 陽性であつた。しかも30例中の28例 は尿浸透圧が $600 \mathrm{mOsm} / \mathrm{L}$ 以下であることから, 至適 浸透圧と $\mathrm{pH}$, 組織中よりの血清成分の流出など各種 の条件が備つた場合には尿中でもオプソニン効果が得 られる可能性はあると思われた。

Suzuki ら ${ }^{13}$ は尿浸透圧が200 $500 \mathrm{mOsm} / \mathrm{kg}$ の AC 尿中では正常尿上りも酵母打よび E. coli の貪食率が 高かつたと述べているが，今回の著者の実験的検討で は $500 \mathrm{mOsm} / \mathrm{L}$ 以下の $\mathrm{AC}$ 症例が 2 例しかなく比較は できなかつた. Suzuki らは検体としての尿の採取方法 として, 患者に採尿前に大量の飲水を命じて得ている。 著者が行つた 72 例の $\mathrm{AC}$ 症例の尿浸透圧測定では, 500 $\mathrm{mOsm} / \mathrm{L}$ 以下のものは 9 例 (12.5\%) にすぎず，排尿 量の少ない場合も多く，500 mOsm/L 以下の $\mathrm{AC}$ 尿の 採取は困難であつた。しかし，少なくとも慢性尿路感 染症の尿についてみる限り，Lab-Tek chamber 法で も, tube 法でも貪食率に及ぼす影響は正常尿と変わら なかつた。これは細菌が多数存在していた感染症の上 清を使用しているため, 細菌の endotoxin や exotoxin によつて好中球機能を抑制した可能性も考兄られる.

細菌の種類によつて ACB の陽性率や貪食率に差を 認めるか否かといら検討は興味あるものと思われる が, 急性の UTI では $82 \%$ E E. coli で, 他菌種が $1 \sim 2$ 株ずつと少なく，慢性の UTI では混合感染例が多く， これらについて検討は困難なため今回は見解を差し控 えたい。また，尿路腔内での白血球の細菌の貪食が， 組織内での細菌の貪食と比較してどの程度の割合と感 染防御の役割を演じているかについては，今後検討す べき問題と考える。

\section{VI. 結 語}

尿路感染症（UTI）患者の尿中の白血球の貪食能に ついて検討し，以下の結論を得た。

（1）UTI患者の尿中の白血球は汪とんどが生存し て打り，その平均生存率は $82 \pm 13 \%$ であった生存率 と尿浸透圧，尿 $\mathrm{pH}$, 疾患などと一定の関係は認められ なかつた。

（2）尿中の白血球で細菌を貪食しているものは少な からず認められ，その全体の白血球に対する割合（貪 食率) は尿浸透圧が $600 \mathrm{mOsm} / \mathrm{L}$ 以下, 尿 $\mathrm{pH}$ が $7 \sim 8$ で高値であつた。急性膀胱炎，急性腎血腎炎，慢性膀 脱炎，慢性腎盂腎炎の各疾患に扣ける平均貪食率はそ

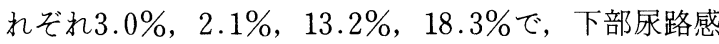
染症と上部尿路感染症との間には貪食率の差は認めら れなかつたが，急性のUTI は慢性のUTI より貪食率 が有意に低值であつた。

急性の UTI では尿中の細菌にかかわらず貪食率は 低值であつたが, 慢性の UTI では菌数の増加につれて 貪食率も增加した。 また，慢性のUTIでもカテーテル 留置例はとくに貪食率が高值であつた。

（3）急性膀胖炎，急性腎孟腎炎，慢性膀羘炎，慢性 腎盂腎炎の antibody-coated bacteria (ACB) の陽性 率はそれぞれ $16.7 \% ， 80.0 \% ， 73.9 \% ， 93.8 \%$ でつ た。 カテーテル留置の慢性膀胱炎症例は全例 ACB 陽 性であり，非留置の慢性膀胼炎でも58\%の症例が陽性 であつた.ACB 陽性と尿中の白血球の細菌貪食率との 関係から ACB のオプソニン効果を検討したが決定的 な結果は得られなかつた。

（4）末梢血多核球を分離し，ミリポアフィルターを 通した正常尿と感染尿中で酵母の貪食実験を施行し た。ガラス表面に付着した多核球の貪食を検討する Lab-Tek chamber 法では，正常尿，感染尿とも800 $\mathrm{mOsm} / \mathrm{L}$ まで尿浸透圧にかかわらず20～30\%の多核 球が酵母を貪食した。 tube法では尿浸透圧が600 $\mathrm{mOsm} / \mathrm{L}$ を越えると貪食は行われず, $600 \mathrm{mOsm} / \mathrm{L}$ 以 下でも貪食率は $5 \%$ \%下であつたが, tube を遠沈し， 接触機会を増加させると， $600 \mathrm{mOsm} / \mathrm{L}$ 以下では著明 に貪食率が増加した。正常尿と感染尿で貪食率に及注 す差異は認められなかつた。

（5）各種尿路感染症患者の尿中の白血球を透過型電 子顕微鏡で観察した。新鮮尿では多核球の顆粒や細胞 内小器管もよく保たれていた. 感染尿中へ latex 粒子, 無菌性膿尿中へE. coli を注入した結果, 数\%ではある がこれを弇食していることが電顕的に確認された。 
（6）以上の結果から, 尿中の白血球は生存しており, 尿浸透圧が低く, 尿 $\mathrm{pH}$ が適当などの条件が整学ば, 尿 中でも細菌を貪食する能力を有しているものと考えら れた。

ゆえに，尿中の白血球は単なる組織からの流出産物 ではなく, 感染防御に寄与しているものと考えられた。

稿を終わるにあたり, 御指導, 御校閲を賜つた恩師西浦常 雄教授に深甚なる謝意を表すると共に，絶えざる御助言を 賜つた河田助教授に深く感謝いたします.さらに, 実験に御 協力いただいた当教室諸兄姉, ならびに彦根市立病院, 検査 主任 国松昭二先生に深く感謝いたします.な招, 本論文の 要旨は第29回和よび第30回日本化学療法学会西日本支部総 会にて発表した。

\section{文献}

1) Chernew, I. and Braude, A.I.: Depression of phagocytosis by solutes in concentrations found in the kidney and urine. J. Clin.Invest., 41, 1945-1953, 1962.

2) Norden, C.W., Green, G.M. and Kass, E.H.: Antibacterial mechanisms of urinary bladder. J. Clin. Invest., 47, 2689-2700, 1968

3) Bryant, R.E., Sutcliffe, M.C. and Mc Gee Z.A. : Human polymorphonuclear leukocyte function in urine.Yale J. Biol. Med., 46, 113-124, 1973.

4) Fukushi, Y., Orikasa, S. and Kagayama, M. : An electron microscopic study of the interaction between vesical epithelium and $\mathrm{E}$. coli. Invest. Urol., 17, 61-68, 1979 .

5）西村泰司, 金森幸界, 秋元成太, 川井 博：前立腺 液中のマクロファージに関する研究. 第 1 報. マク ロファージの検出方法について. 日本泌尿器科学 会雑誌, 72, 785-789, 1981.

6) Sternheimer, R. : A supravital cytodiagnostic stain for urinary sediments. J.A.M.A., 231, $826-832,1975$.

7) Sternheimer, R. and Malbin, B. : Clinical recognition of pyelonephritis with a new stain for urinary sediments. Am. J. Med., 11, 312-323, 1951.

8) Silverg, D.S., Jackson, F.L. and Bryan, L.E. : Antibody coated bacteria in the urine of preschool and school-aged girls with asymptomatic bacteriuria. CMA Journal, 115, 1091-1093, 1976.

9) Knoll, B.F., Johnson, A.J., Pearce, C.W. and Rebuck, J.W.: The effect of autogenous urine on leukocytic defenses in man. Invest. Urol., 6, 406-411, 1969.

10) Suzuki, Y., Fukushi, Y., Orikasa, S. and Kumagai, K. : Opsonic effect on normal and infected human urine on phagocytosis of Escherichia coli and yeasts by neutrophils. J. Urol., 127, 356-360, 1982.

11) Maeda, S., Deguchi, T., Kanimoto, U., Kuriyama, M., Kawada, Y. and Nishiura, T. : Studies on the phagocytic function of urinary leukocytes. J. Urol., 129, 427-429, 1983.

12）宇佐美一彪，伊藤機一：尿沈査細胞成分の生死判 定について。交通医学，31(臨時号)，36，1977.

13) Triger, D.R. and Smith, W.G.: Survival of urinary leukocytes. J. Clin. Path., 19, 443-447, 1966.

14) Guthinger, W.P., Pranikoff, K. and Cockett, A. T.K.: Cytochrome staining of leukocytes in urine sediment. Assessment of inflamatory state.Urology, 9, 630-633, 1977.

15) Berman, L.B. and Schreiner, G.E.: Observation on the glitter-cell phenomenon, N. Engl. J. Med., 255, 989-991, 1956.

16) Cobbs, C.G. and Kaye, D.: Antibacterial mechanisms in the urinary bladder. Yale J. Biol. Med., 40, 93-108, 1967.

17）出口 隆, 前田真一, 蟹本雄右, 河田幸道, 西浦常 雄：マウス実験的上行性腎孟腎炎に打ける細菌の 実質内侵入経過についての電子顕徵鏡的観察. 第 29回日本化学療法学会西日本支部総会, 広島, 1981.

18) Thomas, V., Shelokov, A. and Forland, M. : Antibody-coated bacteria in the urine and site of urinary-tract infection. N. Engl. J. Med., 290, 588-590, 1974.

19) Jones, S.R.: Prostatitis as cause of antibodycoated bacteria in urine. N. Engl. J. Med., 291, 365, 1974.

20) Rumans, L.W. and Vosti, K.L.: The relationship of antibody-coated bacteria to clinical syndromes (as found in unselected popul:ations with bacterituria). Arch. Intern. Med., 138, 1077-1081, 1977.

21) Merritt, J.L. and Keys, T.F.: Limitations of the antibody-coated bacteria test in patients with neurogenic bladders. J.A.M.A., 247, 1723-1725, 1982.

22）安本亮二, 岩井省三, 过田正昭, 成山隆洋, 西島高 明, 井関達男, 坂本 亘, 吉本 充, 前川正信: 泌 尿器科領域における Antibody coated bacteria (ACB) の臨床的検討一続報一第32回泌尿器中部 連合総会, 名古屋, 1982.

23) Riedasch, G., Schneider, E., Ritz, E, Bersch, W. and Möhring, K. : Antibody coating of bacteria in experimental infection of the urinary bladder. Invest. Urol., 18, 247-250, 1981. 
24) Riedasch, G., Ritz, E., Möhring, K. and Bommer, J.: Antibdy coating of urinary bacteria : Relation to site of infection and invasion of uroepithelium. Clin. Nephrol., 10, 239-244, 1978.
25) Smith, J.W., Jones, S.R. and Kaijser, B.: Significance of antibody-coated bacteria in urinary sediment in experimental pyelonephritis. J. Infect. Dis., 135, 577-581, 1977.

(1983年 3 月 18 日受付) 